\title{
Research on the Guarantee Mechanism of Modern Apprenticeship From the Perspectives of Stakeholder Theory
}

\author{
Qiying Zhang ${ }^{1,2, a}$ \\ ${ }^{1}$ Soochow University, Jiangsu 215021, China; \\ ${ }^{2}$ Suzhou Vocational Institute of Industrial Technology, Jiangsu 215104, China. \\ a458843325@qq.com
}

Keywords: modern apprenticeship, stakeholders, guarantee mechanism.

\begin{abstract}
Modern Apprenticeship is going to adapt to the changes of technological and environmental situation, promoting the reform of highly skilled talents. And the key step is to establish and develop the guarantee mechanism of Modern Apprenticeship. This article starts with the connotation of modernity of Modern Apprenticeship, analyzing the interests of different stakeholders. The author puts forward several paths in implementing Modern Apprenticeship in China from the aspects of legal protection, implementation guarantee, management system and assessment and evaluation.
\end{abstract}

\section{Introduction}

Apprenticeship is not a new word in China. But Modern Apprenticeship has been the subject of intense scholarly debate in the area of vocational education. There are two reasons for the discussion about the issue. Many vocational schools have faced the troubles in training technical talents in China which make them look for the new ways to deal with the difficulties. And the international reform of Modern Apprenticeship has achieved demonstrable results. Combining the inner demands and external experiences, Modern Apprenticeship has been the new model in training technical talents in China. And the key step is to establish and develop the guarantee mechanism of Modern Apprenticeship.

\section{The Connotation of Modernity of Modern Apprenticeship}

The modes of production has totally changed with the mass production of industrial, replacing the traditional manual production. The traditional apprenticeship has limited the people's diversified development, training effects and the normalization of education. Therefore, training technical talents in vocational schools has dominated, with the flows of theory divorcing from practice. Modern Apprenticeship emerged. Modern Apprenticeship has a lot in common with the traditional apprenticeship. They both have the master-apprentice relation in the instruction and learning, emphasizing learning by doing. But, they have the significant differences, including the macroscopic level such as the background, system and organization, and the micro level such as concrete mode, the relationship, and the subjects etc. Firstly, from the perspective of economic and social background, Modern Apprenticeship was applied for the intelligent manufacturing, not applying for the manual production and traditional industry. Secondly, Modern Apprenticeship demands a more well-rounded system. Thirdly, from the perspective of performing organization, Modern Apprenticeship demands the participation involving the schools, enterprises, teachers and students. Fourthly, its talent cultivation model bases on the school-enterprise cooperation. Lastly, it trains people to meet the needs of modern industries. All these differences make the Modern Apprenticeship has more practical significance. 


\section{The Stakeholders and Their Interests of Modern Apprenticeship}

Carrying out Modern Apprenticeship needs all the efforts from stakeholders. From the current situation, the higher vocational colleges, enterprises, teachers and students are the basic stakeholders in the guarantee mechanism. All of the stakeholders have their own interests, roles and demands.

\subsection{Higher Vocational Colleges and Their Interests}

The main task of higher vocational college is to cultivate the qualified technical talents. Implementing the Modern Apprenticeship contributes to this task. The basic interests of the colleges are to get more opportunities of improving vocational skills and expanding employment channels, to

Realize their training objectives, and to increase their ability of social service and cultivating talents. Meanwhile, higher vocational colleges are going to promote the Modern Apprenticeship by the school-enterprise cooperation, planning the concrete and effective program, integrating the resources of every stakeholder, arousing the enthusiasm of enterprises, teachers and students, and achieving the deeper integration between industry and education.

\subsection{Enterprises and Their Interests}

Enterprise is such an organization which combining by different capitals aimed to profits. Its basic model of development is to participate in the market competition, providing the products or service, obtaining the financial rewards, and achieving the long-term development. Modern Apprenticeship is a new measure to cultivate technical talents, which takes the enterprise as one of the most important stakeholders. The enterprises' interests is to seek matching between the enterprises' needs and technical talents with the minimal time, cutting their labor cost. The existence of the enterprise is based on the purpose of profit. The interests of the enterprises is to attract the technical talents directly and conveniently. Moreover, with the participation and efforts, the enterprise wants to get more economic and social benefits, such as sharing the machinery equipment in the higher vocational colleges, sharing the teachers' technology, and promoting the enterprises' popularity, etc.

\subsection{Students and Their Interests}

The students are both the consumers and beneficiaries of education. They also have the most quantity in stakeholders. One of the reasons that Modern Apprenticeship has been concerned is that it really shows significant improvement in students' practical skills. Although many students want to train skills by closing to the practice, they will be worried about the performance of the true task from the enterprise. The students' interests is to learn the fundamental theory, to enhance their practice skills, to acclimatize themselves. They accept the vocational education, training their skills, improving their employment competitiveness.

\subsection{Teachers and Their Interests}

Usually, the teachers organize the teaching activities and direct the students. For the higher vocational colleges, they are also employees accepting the leading of managements. For the teaching activities, they are the direct organizers and executors in education, guiding the students to learn and train. They cannot to be ignored in any modes of cultivation activities. The boundary between teaching in colleges and practicing in enterprises has always to be broken by the Modern Apprenticeship. So does the boundary between students and workers. The teachers also have to adjust the teaching plan. Besides, the teachers will pay more attention to the needs of their own. They hope that they will get the stable income, good working condition, and the opportunities of promotion. They also concern the rights to participate in the management and decision, such as how to carry out the teaching, how to choose the books and the methods of teaching.

\subsection{Governments and Their Interests}

As the macro manager, the governments although don't participate directly in the cultivation of technical talents, they have played the roles of director and protector. Owing to the efforts made by all stakeholders, Modern Apprenticeship has achieved smoothly. It cannot play a role without any stakeholder. Therefore, the governments should take into account the interests of every stakeholder, adopting policies to identify the rights and obligations of stakeholders. Meanwhile, as the investor, the governments also hope that they will get the rewards, such as more important functions that higher vocational colleges will exercise, more technical talents that higher vocational colleges will cultivate. 
The governments play the different roles in the education in China. Their interests is to enhance the quality of technical talents, to promote the capability and accomplishment of people, and to meet the social needs of talents training.

\section{The Guarantee Mechanism of Modern Apprenticeship}

\subsection{Legal Protection}

The governments have to adopt policies if the Modern Apprenticeship is to be spread, which we can conclude from the experience of British and American practices.

The higher vocational colleges want to implement the Modern Apprenticeship which involved many stakeholders, such as the government, the vocational colleges, enterprises, students and teachers. Either stakeholder plays a special role during the progress. We should identify the rights and obligations of every stakeholder, clarify the objectives and standard of the Modern Apprenticeship. On the other hand, every stakeholder should be protected by the policies.

However, in terms of current situation, all the present laws and policies have not mentioned the legal status of Modern Apprenticeship in China. Nowadays, the development of higher vocational education is embarking on a new stage with the characteristics of multilateral participation and win-win cooperation. It's an urgent task to perfect the laws and regulations about Modern Apprenticeship. The major concerns of the laws and regulations include the legal identity of every stakeholder, basic rights and obligations, and the support measures.

\subsection{Implementation Guarantee}

Modern Apprenticeship wouldn't achieve expectedly without the participation of enterprises. Throughout the practice of international world, the enterprises always play a key role in Modern Apprenticeship. Enterprises have provided the practice place, technical experts, actual task and operating machines by cooperating with the higher vocational colleges. Enterprises have invested a great deal of resources. So, it is necessary to guarantee the rewards of their investigation. The Modern Apprenticeship can continue and carry out only if the enterprises can benefit from the apprenticeship. For example, the enterprises can get the tax incentives, obtain the funds support by take part in the Modern Apprenticeship.

\subsection{Management System}

Modern Apprenticeship will get rid of the bondages of traditional teaching model, adjusting the relationship between teachers and students. It will break through the limits of colleges and enterprises, education and industry, students and employees. And it demands the more flexible, open and inclusive vocational colleges. According to the Modern Apprenticeship, colleges usually carry out the teaching and learning activities in the practice situation of enterprises, not class-centered. It both changed in the management of students and teachers. The students always changed their roles between students and workers, and the teachers always changed their roles between teachers and coordinator. Implementing the Modern Apprenticeship needs to carry on a scientific plan, to supply overall support for it.

\subsection{Assessment and Evaluation System}

To implement Modern Apprenticeship in the area of vocational education in China is based on the inherent requirements of the development of vocational education and the effects achieved by the international world. But there are many difficulties for the implementing of apprenticeship, which needs all stakeholders to be deeply involved and interacted. The higher vocational colleges also have to transform the approach of assessment and evaluation, taking all efforts into account, carrying out the different ways of assessment and evaluation, making every stakeholder benefit from its pays and efforts.

\section{Summary}

The guarantee mechanism of Modern Apprenticeship means the cooperation of every stakeholder during the process. The cultivating objectives of vocational education will carry out through the 
efforts of all parties, such as the government, enterprises, higher vocational colleges, students and teachers. Constructing the increasingly perfect guarantee mechanism of Modern Apprenticeship is not only the necessary condition of improving the quality of technical talents, but also a foundation of the reform of talent cultivation mode.

\section{References}

[1]. Zhenhong Wang, Jun Cheng. Modern Apprenticeship: A New Model for the Cultivation of Hi-Tech Talents. China Higher Education Research. Vol.13 (2012) No.8, p. 93-96.

[2]. Wensheng Jia, Jianfeng Pan, ET. Construction of Modern Apprenticeship in Higher Vocational Colleges:the System Bottleneck and Strategies. Journal of East China Normal University (Educational Sciences). Vol.35 (2017) No.1, p. 47-53.

[3]. Qifu Zhang. Modern Apprenticeship System in Higher Vocational Colleges and Universities: Predicament and Practical Strategies. Research in Education Development. Vol.36 (2015) No.3, p. $45-51$.

[4]. Yuegang Peng, Weiping Shi. Historical Change Operation Mechanism and Enlightenment of American Modern Apprenticeship: Taking Registered Apprenticeship for Example. Studies in Foreign Education. Vol.44 (2017) No.4, p.103-114. 